\title{
Explore, experiment, experience: A synthesis of Vickers' appreciative learning system and Ackoff's problem approach applied in practice
}

\author{
Dr Christine Welch, Portsmouth Business School, UK \\ Dr Paul Summers, Winchester Business School, UK
}

\begin{abstract}
This chapter will explore the application of a problem-structuring approach which synthesizes Vickers' concept of 'appreciation', Bateson's learning spirals, and Ackoff's approach to dealing with problems. This problem structuring approach involves three elements; explore, experiment, experience. The chapter describes, as an example, a case study taken from a United Kingdom unitary authority (anonymized for convenience) in which attempts were made to improve project performance using this approach. The organisation commissioned projects across multiple disciplines e.g. transport schemes, constructions, change programmes, business improvements using IT and bridge replacements, but was rated as poor at project management by successive internal and external reviews. Some conclusions are offered about the application of problem-structuring in order to learn lessons and promote good practice for the future.
\end{abstract}

\section{Introduction}

The field of project management has been characterized by uncertainties. While there is broad agreement that projects should be managed in order to progress both efficiently and effectively, there is a lack of agreement on many key points: not least definitions of the nature of a 'project' and the activities that should comprise 'project management'. Inevitably, project failures tend to attract public attention, especially those public sector projects in which large amounts of tax-payer funds are expended. It is, perhaps, unfortunate that rather less attention is paid to learning lessons from successes. In the past decade, researchers have pointed out an important theme - lack of attention to the complexity of projects (Winter and Smith, 2006). Too often, projects and their environments have been simplified for the convenience of management tasks, with consequent loss of richness. The multiple perspectives and desires of engaged stakeholders have become invisible, as the 'iron triangle' of cost, time and quality are given central importance.

This chapter will explore the application of a systemic problem-structuring approach which synthesizes Vickers' concept of 'appreciation' (Vickers, 1965, pp. 39-40); 1968, p.134), Bateson's learning spiral (Bateson, 1972) and Ackoff's approach to dealing with problems (Ackoff, 1994, p. 185). A case study is introduced, based on real world research in a UK unitary local authority. At the commencement of the study, the organization was commissioning a diverse range of projects, but was rated as poor at project management by 
the both internal and external reviewers. The case explains how a model was derived through efforts to structure and dissolve this problematic situation.

Vickers (1965, pp. 39-40; 1968, p.134) suggests that the expression 'appreciation' be used for the judgments of reality and of value that all individuals (and groups) constantly make. For Vickers 'appreciative settings' are the unique beliefs, values and experiences of an individual or society which colour judgments made. These settings are derived over time and are always latent, developing as judgments are challenged or confirmed by experience. Crawford and Costello (2000) consider 'appreciation' within a context of project management practice. Building on Checkland and Holwell (1998, p.104) they suggest that individuals, groups and organizations have differing 'appreciative settings' and further that there is a reflexive relationship between the world of ideas and the world of action, in which a continual cycle of reflection and change in those settings may be perceived.

As Ackoff (1994 p.185) suggests:

'Managers are not confronted with separate problems but with situations that consist of complex systems of strongly interacting problems. I call such situations messes.'

This suggests that efforts to pursue a project in isolation from its context may result in an even tighter 'mess' emerging.

An inquiry was launched into current project management practice within the authority. By exploring multiple perspectives, it was possible to gain understanding of the 'appreciative settings' of stakeholders, who often appeared to have conflicting and/or competing objects in view. This approach shed light on many dimensions and dynamics of the problem situation. Application of Systems thinking highlighted three key elements: governance, learning and a Community of Practice.

\section{Background}

\section{Systems Thinking}

The concept of a System describes phenomena that are formed by interactions among a group of smaller elements, featuring communication and control (Von Bertalanffy, 1950). Systems subsist within defined boundaries, reflecting the interest of an observer who chooses to regard them as interacting wholes. They exhibit properties of hierarchy (i.e. it is possible to perceive narrower systems nested within wider), and emergence (i.e. the whole demonstrates qualities that are not present in a mere collection of its elements). When defining a purposeful system, it is important to consider from whose point of view a particular description will make sense. Checkland (1999) suggests a number of factors that any definition should include: What transformation is the intended purpose of the system and from whose perspective does this make senses? Who is affected by the outcome of the system's operation? Who will take part in the various activities inherent in the systems operation? Who is responsible for resourcing and maintaining the system to achieve its purpose? Within what environment does the system operate?

Looking at the various formal definitions of 'projects' it is possible to view any given project as an organized system, with a hierarchical structure of functioning sub-systems, interrelated 
via channels for monitoring, feedback and communication. A boundary has been set, differentiating this system from its environment, i.e. those aspects of the world which influence system behaviour but cannot be controlled from within it. This is effectively a closed systems view, within which a project may be managed (see Figure 1).

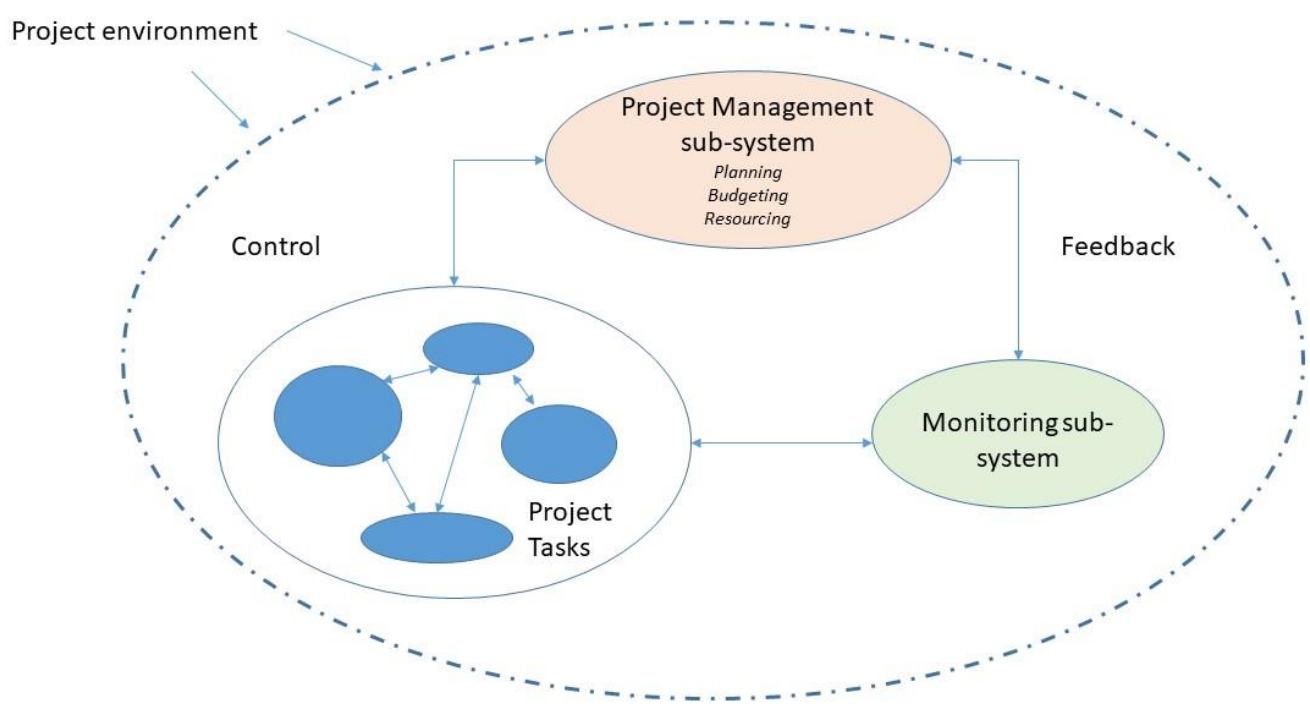

Figure 1: Projects as closed systems

However, as Checkland and Poulter (2006, p.56) point out, at any particular time, organizational behaviour subsists as an accommodation between differing perspectives of stakeholders. This suggests that the view shown in Figure 1 represents only a 'snapshot' of a phenomenon that is dynamic and constantly changing. As Mumford (2006) points out, an open systems perspective on organizations may be preferable. Any organization subsists from moment to moment as an emergent property of the interactions among the people who are its members (Bednar, 2007). In the context of networked organizations, dynamic complexity is not merely expanded but radically altered.

Bednar (2007) describes a view of organizational emergence, recognizing that any individual component of a purposeful activity system may possess emergent properties that are greater than the 'whole'. Individual components may be participating in several perceived 'Systems' at the same time (reflecting our multifaceted experience of 'real' life). Thus, a model of a system may be more akin to a set than a hierarchical model. This may be of particular importance in relation to project management in a local authority, where a problem owner of one project may be an engaged actor in others. The system under consideration and any of its component systems are open and dynamic in a multidimensional way. Boundaries are not fixed but subject to continual re-drawing, depending on how the perspectives of interested observer[s] may shift to reflect fluctuating purpose[s] over time (Mumford, 2006). 
Organizational roles can also be seen to fluctuate - created and recreated as the perspectives/intentions of individual actors and their interactions shift.

\section{Appreciation}

Vickers observed that human beings navigate life experience by means of a schema that involves interactions among three systems. The first he describes as a system for making judgments of reality. This is a system we begin to develop in our babyhood, or perhaps even earlier, as we try to make sense of what is out there both in physical and in social terms. Thus, for instance, a child learns that it is not a good idea to touch a hot oven door - the second system is therefore involved with choices among possible actions. Thirdly, and concurrently, individuals and 'societies' develop a system for making judgments of value. $\mathrm{He}$ suggests that our frame of reference is not the existence of objects in the outside world; but maintenance of our relationships with those objects. In his words, no-one wants an apple they want to eat it, make cider from it, perhaps draw it, etc. (Vickers, 1968, p.162)

As we perceive a world outside of ourselves, we also carry on a reflective discussion within in which we evaluate experiences and actions on many dimensions, such as self-interest, expediency and the value judgments of others that are communicated to us in our social/cultural contexts. Such processes of perception, reflection, evaluation, judgment and choice Vickers referred to as 'appreciation'. The norms and values we create, internalize and apply in making judgments and choices, he referred to as 'appreciative settings'. The whole thus expressed can be referred to as an 'appreciative system' (see Figure 2). For Vickers, human living is a process of developing and maintaining relationships that are coherent with an individual or societal appreciative system.

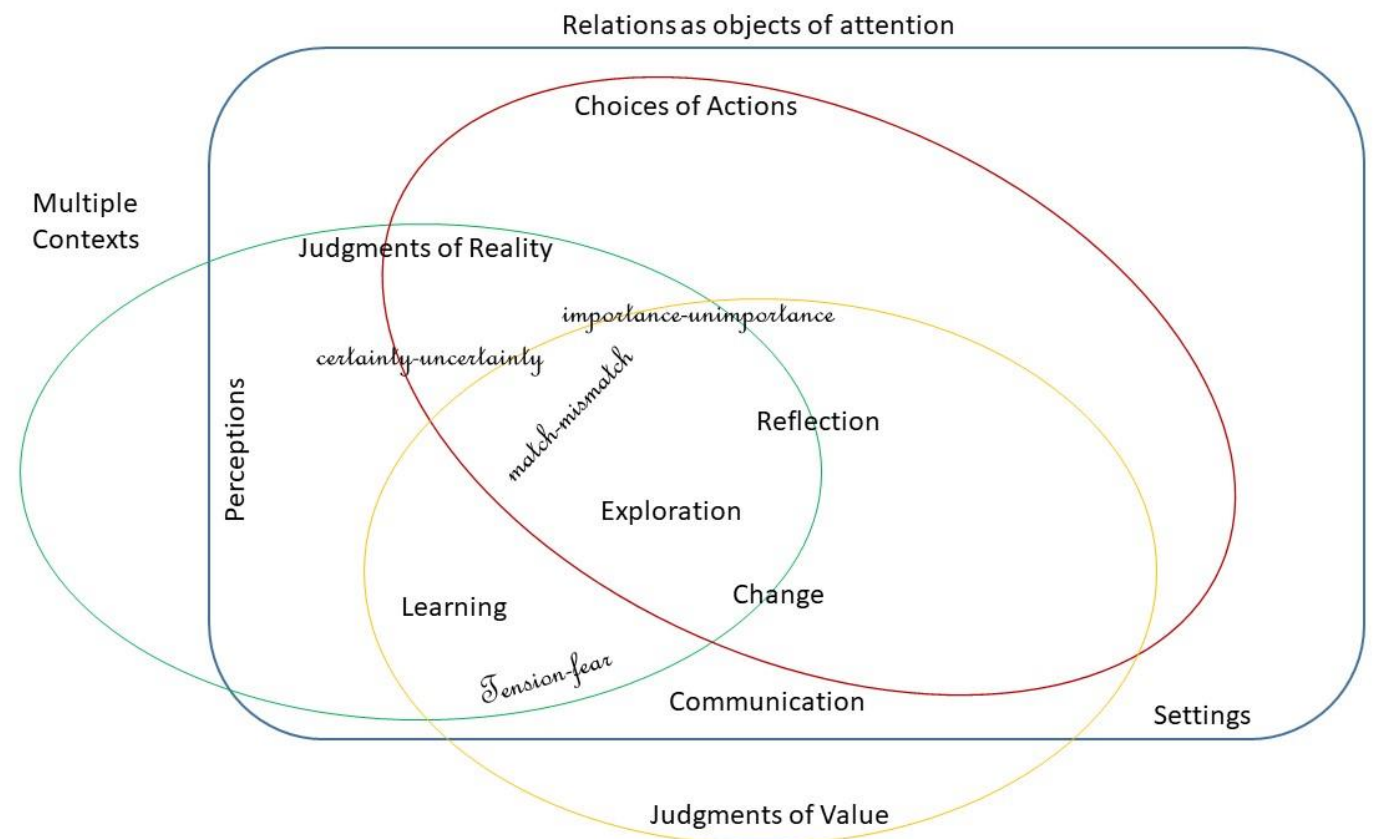

Figure 2: Model of an appreciative system

Change comes about when an individual or group perception of reality (what is) is not congruent with appreciative settings (what ought to be). At the same time, appreciative settings themselves are continually changed and developed through a number of processes, 
such as perceptions of incongruence, reflection and learning. As part of appreciation, judgments are made regarding match or mismatch of experiences with value settings. Where there is mismatch, discomfort arises leading to a desire for change either in actions or in settings. Realization of such desire may depend upon appreciation of factors such as level of certainty surrounding issues and degree of a importance attached to them. A perceived mismatch, accompanied by a judgment of great importance and high uncertainty are likely to lead to tension and possibly fear and/or aggression.

However, appreciation is a reflexive process; current appreciative settings impact upon future perceptions and judgments, at the same time that new perceptions and reflection can impact upon settings. Thus, our appreciative settings affect both the way we perceive and judge reality - what we notice and attribute meaning to - and how we evaluate those perceptions. Vickers points out that appreciative settings are always latent, since at any given time they lurk in the mind awaiting the next opportunity to guide judgment or to be changed through reflection on experience. He writes

\section{'Events call constantly for new appreciations of the "situation". Other people's} communications reveal schemata which confirm or challenge our own. And, apart from both these, the inner inconsistencies and incompleteness of our own schemata call us constantly to revise them. There are the occasions for appreciative behaviour signals, whether of match or mis-match which confirm or question at the same time as they reveal the current appreciative setting of the system' (Vickers, 1983, p. 286).

Complexity in appreciative systems is increased when it is considered that people do not form their appreciative schema in isolation. People are social beings and interact in multiple groups in many overlapping contexts within which formal and informal learning takes place.

Interaction and communication enable people to form shared perceptions and judgments of situations, leading to formation of collective appreciative settings. At times, there may be conflict among appreciative settings derived and applied in differing contexts, leading to stress in individuals similar to that experienced in a double-bind situation (Bateson, 1972).

\section{Learning}

An appreciative system is considered as a continual process of learning, which Vickers suggested to have three, iterative phases, 'information, valuation and action' (Vickers, 1968, p. 130). However, it is important to recognize that such iterations form, not a cycle but a spiral, since learning in each phase generates new understanding for reflection in the next. As conscious human beings, we have no choice but to think and reflect on our experience. When we reflect upon our efforts to solve a problem, we may evaluate different strategies and consider how successful they were in generating more or less useful solutions. We may move from considering how to solve that immediate problem to think about the scope of successful strategies to generate guidance for the future when new problems are encountered. Possibly, as we apply these guidelines in practice, we may reflect over the way in which they were formulated and consider improvements in this process, and so on. This can be seen as a productive learning spiral in which it is possible to engage in deeper reflection and improvement in the learning process itself. Bateson discusses this in terms of levels of reflection and orders of learning (1972, p.287). The purpose of an effort at appreciation in a situation is therefore to build productive learning spirals that will inform further inquiry and practice. 


\section{Problem structuring}

Ackoff (1974) discussed the nature of problem situations, pointing out that in social settings, no problem ever exists in complete isolation:

'Every problem interacts with other problems and is therefore part of a set of interrelated problems, a system of problems ... I choose to call such a system a mess' Ackoff (1974, p.427).

He goes on to point out that an analytical approach to problem-solving, seeking to identify and solve each problem in a system of problems separately, not only often fails to achieve a satisfactory solution but often also serves to intensify the mess. Pidd (2009) builds on this when he categorized the challenges facing decision takers into categories of puzzles, problems and messes. A puzzle is something clearly defined and susceptible of a solution by application of an appropriate method. For example, a project manager who is given a list of tasks to be accomplished and a set of available resources can use critical path analysis to find the shortest timescale to completion and use this to work out loadings for optimal use of labour time. A problem, on the other hand, arises from perception of an unsatisfactory situation when it is not clear what must be done to bring about improvement. This requires exploration, clarification and analysis in order to transform it into a series of puzzles (or decisions). Problems within human systems are difficult to define because they are usually open to interpretations and differences of opinion, as well as interrelationships with other problems - forming a mess. Pidd refers to this when he suggests:

'One of the greatest mistakes that can be made when dealing with a mess is to carve off part of the mess, treat it as a problem and then solve it as a puzzle -- ignoring its links with other aspects of the mess' (Pidd, 2009, p.62)

Why do we make this mistake? Desire to accomplish useful work in a timely way can lead to a related desire to simplify complex situations. Solving puzzles feels productive.

Management Science and Operations Research have developed sophisticated methods for analysis to generate optimal solutions to defined problems.

However, optimal solutions to many separate problematic situations will probably not result in a satisfactory dissolution of a 'wicked' problem (or mess). Sub-optimality arises because what makes things better for one part of a system could be making them worse for another. When parts of a mess are critical (for instance in a military or health service environment) sub-optimal outcomes from decision-making may be catastrophic. Furthermore, when complexity is ignored it is likely that any and all interventions made in efforts to move forward will have the effect of tightening the mess. As Checkland and Poulter (2010) point out:

'the (social) world is taken to be very complex, problematical, mysterious, characterized by clashes of worldview' (2010, p.198).

Ackoff (1981, p.127) defined management as the control of a purposeful system by a part of that system, involving three functions: identifying threats and opportunities; deciding and carrying out action; and maintaining and improving performance under changing and unchanging conditions. However, anyone undertaking activities intended to address these functions must first consider whether the challenges faced constitute a 'mess'. Without such 
insight, difficulties are likely to multiply. For instance, local actors, with limited knowledge of the whole system, will make decisions that appear rational in context, but a combination of all these piecemeal decisions may create unexpected effects upon the whole (Morecroft, 1985). At the same time, interventions at 'whole system' level will be made by people with limited knowledge of the contextual dependencies inherent in every local area (Bednar, 2000), so that any such decision is likely to have further unintended consequences.

Furthermore, as Stacey (1992) pointed out:

'Most Western managers believe that long-term success flows from a state of stability, harmony, predictability, discipline, and consensus - a state that I refer to as stable equilibrium. This belief leads them to demand general prescriptions that they can immediately convert into successful action' (1992, p.xi).

Stacey's view is that such a perspective is useful in reducing anxiety for managers, but it inhibits creativity and stifles innovation in the organization - effectively putting it at greater risk in the long-term. It is axiomatic that the best source of sustainable advantage to a business is the 'know-how' of the people within it (Davenport and Prusak, 2001). However, it was many years before this view was widely embraced as a business imperative. It is interesting to note that Davenport and Völpel (2001) suggested that a further shift of emphasis was needed:

'One of the key battlegrounds in the future knowledge war will be the management of attention: understanding how it is allocated by individuals and organizations, knowing how to capture it more effectively for important information and knowledge, using technology to get, keep, and protect it. Attention is the currency of future business, and is already the scarcest resource in many organizations. In addition to knowledge ... in the future all organizations will need to focus their attention on attention' (2001, p.218).

Attention is clearly an important facet of project management, as is evidenced in the case study that follows.

The future is unknowable and therefore success depends upon ability to live with uncertainty. However, Stacey does not suggest that decision-makers should simply 'go with the flow' but advocates a form of 'bounded instability'. This requires a different mental model from managers, in which attention is paid to continuing interactive feedback and giving explicit recognition to instability and disorder. Stacey refers to 'escalation of small changes and the self-reinforcing virtuous and vicious circles' (1992, p.75).

Ackoff (1994, p. 185) considered that there are four different ways to address problems. A person who perceives a situation to be problematic could simply ignore it and hope it goes away - sometimes it does. This is termed absolution. The second possibility he terms resolution - achievement of a solution that is deemed good enough; or that satisfices to use Simon's view of bounded rationality (Simon, 1956, pp. 129, 136). Resolution relies upon the perceiver's experience and ability to evaluate, and focuses on the uniqueness rather than the generality of a problem. A third possibility is solution, which seeks to optimize outcomes and involves research and experimentation. This focuses on general aspects of a problem situation, and is a common feature of project management methodologies such as PRINCE2. Finally, Ackoff considered dissolution of problems. Dissolution changes the nature of a 
problem situation. It involves a design approach intended to achieve ideal outcomes. This approach eliminates the problem altogether, at least from the perspective of the particular dissolver (one way to dissolve a problem would be to transfer ownership to someone else). There is a focus on both the general and the uniqueness, and draws upon whatever techniques and methods that can assist.

It is vital to consider these strategies within the context of Ackoff's taxonomy of problematic situations - action that would dissolve a puzzle would be ineffective in relation to a mess. Efforts to resolve a part of a messy situation may well permit useful progress, but only providing it is undertaken in a realization that it is a partial resolution and that a complex 'whole' remains to be addressed. Systems thinking is capable of yielding insights into the nature of the phenomenon examined; and methods of understanding the phenomenon (Van de Ven, 2007, p. 36), and additionally enables inquirers to consider different perspectives on the phenomenon, giving a fuller picture to support problem dissolving.

\section{Projects and Project Management}

A project is a bounded piece of work. Formal definitions vary (see Table 1), but most emphasize a temporal boundary as well as defined objectives or outputs. All projects follow a similar pattern, a series of steps,

1. The idea or initiative, what is to be achieved, problem solving, the purpose

2. Feasibility, outlining the concept, selecting from different options, producing the business case

3. Planning and design the activities, analysing risk and stakeholders

4. Delivering or executing the project, applying the plans, monitoring progress

5. Completion, handover of output.

This is often termed as a project 'life-cycle'. However, arguably, this should be extended to cover a sixth step - benefit realization - so that the focus is upon the purpose for which the project was undertaken (British Standards Institute, 2010, p. 26). For this reason, Step 5 could be better expressed as 'transformation' - enabling benefits to be realized.

\section{The three most influential definitions of a 'project' in the UK:}

\begin{tabular}{|l|l|}
\hline Prince2 & $\begin{array}{l}\text { A project is a temporary organisation that is } \\
\text { created for the purpose of delivering one or } \\
\text { more business products according to an } \\
\text { agreed Business case. }\end{array}$ \\
\hline $\begin{array}{l}\text { Project Management Institute } \\
2008\end{array}$ & $\begin{array}{l}\text { A project is a temporary endeavour } \\
\text { undertaken to produce a unique product, } \\
\text { service or result. }\end{array}$ \\
\hline Association for Project Management & $\begin{array}{l}\text { A unique, transient endeavour undertaken } \\
\text { to achieve planned objectives }\end{array}$ \\
\hline
\end{tabular}

Table 1: Alternative definitions of the project concept. 
The term project manager was first used by the Harvard Business Review in 1959 by Paul Gaddis, (Morris, 2013, p. 60) and several authors suggest that project management as it is currently understood was formalized during the 1960s as the project management associations became established and bodies of professional knowledge developed. Since that time, knowledge about project management practice has continued to be expanded through iteration into coherent views of what is good professional practice (Lenfle and Loch, 2010; Morris, 2013). However, this can be seen to have led to a dichotomy - a disconnect between success from the project manager's perspective and success from the project sponsor's perspective (Burke, 2011, pp.27-28). Cooke-Davies (2002) suggests that there is a need to separate evaluations of project success and project management success. As Dalcher (2016, p. 2) points out:

'Sponsors support projects and programmes in order to ensure that the benefits are realized and the promised value is delivered (i.e. in order to satisfy some business goals, strategic objectives and intentions)'.

Marchand and Hykes (2006) discuss this apparent dichotomy in relation to IT-related projects. They suggest a need to shift the focus from deployment as the end point of a project to successful usage, and propose four principles for future practice:

1. Recognize that IT projects are not about IT, but about people using information and IT to execute business tasks and processes;

2. In the business/IT governance process, measure and determine the business area's level of effectiveness in information, people and IT practices BEFORE approving a project's plan and budget;

3. Include information and IT usage in every IT-enabled business project: before, during and after deployment activities;

4. Include information and IT usage as a key business success factor to drive IT enabled business projects.

Clearly, a similar set of principles might be derived for projects more generally that would tend to bring together the two potentially dichotomous views of 'success' to focus upon the interests of sponsors and other stakeholders. In 2004, a UK Government-funded inquiry was launched, aiming to draw up an agenda for new research to generate fresh ideas on project management practice (Winter, Smith, Morris and Cicmil, 2006). Two years later, a report was published identifying five areas for research (Winter and Smith, 2006).

1. Moving from a lifecycle model of Projects and Project Management towards theories of the complexity in projects and PM;

2. Moving from seeing projects as instrumental processes towards seeing them as social processes;

3. Moving from viewing product creation as the prime focus towards a perspective that value creation is the prime focus;

4. Moving from a narrow to a broader conception of projects;

5. Moving from a view of practitioners as trained technicians towards seeing them as reflective practitioners.

(Winter and Smith, p.642) 
One of the challenges specifically considered in this study was a need to address complexity. All projects consist of multiple activities and actors, subject to interdependencies and, interrelationships within a dynamic business/organizational context. Actors may be concerned in more than one project at any given time. They must make sense of their situation taking into account their contextually-dependent day-to-day experiences. However, the concept of 'a project' suggests a single coherent unit to be managed, tending to create a silo perspective, in which the focus is upon tactics and operational effectiveness rather than strategic importance. Criteria for evaluation may be narrowed accordingly. Atkinson (1999, p. 340) pointed out that definitions of success for project managers had not changed over the 50 years since the profession was established. Criteria still focused around the so-called 'Iron Triangle' of cost, time and quality. Additionally, Kerzner and Saladis (2009, p. 7) offer the view that:

'...decision making based entirely on the triple constraint, with little regard for the final value of the project, may result in extreme stakeholder dissatisfaction or significant opportunity cost.'

It may be argued that most if not all projects involve some level of uncertainty during their currency, and practitioners need capability to embrace and deal with this uncertainty. Stacey (1996) suggests that a combination of uncertainty and lack of agreement are the constituents of complexity.

Atkinson et. al. (2006, p. 688) suggest developing '...less tangible... more generic management processes...' moving the focus away from 'operational planning and control.' These authors list several areas were uncertainty may exist and suggest that good continual communications would ameliorate some of these.

Whitty and Maylor (2009, p. 306) point out that uncertainty alone is not an indicator of complexity, which they define as follows:

'A complex system is a system formed out of many components whose behaviour is emergent. That is to say that the behaviour of a complex system cannot be simply inferred from the behaviour of its components.' (2009, p. 305)

This suggests that interventions based upon analysis, looking at component parts of a problem, will not predict or modify behaviour.

Winter et al (2006, p.75) suggest taking a view that a project represents an intervention into a situation experienced as a problem by some group or organization. This perspective serves to maintain project context in view, and suggests a journey progressing from problem situation to a new improved state which is desired by stakeholders (this can be likened to the 'what is' and 'what ought to be' of Vickers' appreciative system). Thus, projects and the wider organizations involved in delivering them may best be conceived as purposeful human activity systems (Checkland, 1999, p. 314), in which processes cannot be separated from the people involved in them (Winter \& Smith, 2006, p. 13).

\section{Case Study}

The organization in which this study is set we will call Exton Community Council. This is a UK unitary local authority situated in south-east England. It has responsibility for education, 
social services, leisure, culture, Town and Country Planning, Environmental Health, Trading Standards, waste collection, housing, traffic and street management, collection of council tax and non-domestic rates, civil contingencies and network safety within its boundary. Exton is situated on the coast and was formerly a garrison town, which still has a military presence. The population is currently about 207,100 within an area of 40 square kilometres.

The Council's broad responsibility means that it undertakes projects often involving several different disciplines in combination, e.g. change initiatives, Information Technology developments, construction, civil engineering and traffic engineering. Four projects are described here as representative of the kinds of challenge faced in terms of project performance and demonstrating the need to bring about improvement (see Table 2).

\begin{tabular}{|c|c|}
\hline \multicolumn{2}{|l|}{ Examples of project undertaken by ECC } \\
\hline Project & Comments \\
\hline $\begin{array}{l}\text { 1. The Millennium Project. } \\
\text { In } 1995 \text {, the Council received funding from } \\
\text { the Millennium Commission to build a } \\
\text { public amenity celebrating Exton's history } \\
\text { and contributing to regeneration of the } \\
\text { town. This was scheduled for completion } \\
\text { before } 31 \text { December 1999, but the project } \\
\text { was subject to delays and the facility was } \\
\text { not, in fact, opened until October } 2005 \text {. } \\
\text { This project exceeded budget by } 116 \mathrm{M} \text {, } \\
\text { triggering an internal review and also an } \\
\text { independent review by the Audit } \\
\text { Commission. As a result, the Leader of the } \\
\text { Council resigned and a senior officer took } \\
\text { retirement. Failure to open this public } \\
\text { amenity generated much criticism among } \\
\text { the public, expressed in the local Press } \\
\text { There were further political repercussions as } \\
\text { a result of public criticism with control } \\
\text { changing to a different Party. } \\
\text { Subsequently, the amenity proved very } \\
\text { popular, attracting visitors to the town and } \\
\text { generating both public satisfaction and new } \\
\text { income streams. These benefits came as a } \\
\text { pleasant surprise to the Council, as they had } \\
\text { not been anticipated. }\end{array}$ & $\begin{array}{l}\text { Post-project reviews revealed: } \\
\text { No formal project management was put in } \\
\text { place. This project suffered from poor } \\
\text { contract management and poor selection } \\
\text { processes in selection of contractors. } \\
\text { Lack of effective project management led to } \\
\text { impaired stakeholder engagement. } \\
\text { These failings led directly to delays; } \\
\text { penalties incurred by ECC added to costs } \\
\text { and the budget was exceeded. } \\
\text { Recommendations were made for future } \\
\text { practice to prevent such problems recurring. } \\
\text { Benefits management was not considered. }\end{array}$ \\
\hline $\begin{array}{l}\text { 2. The special school. } \\
\text { A project to construct a special school }\end{array}$ & $\begin{array}{l}\text { Three reviews took place after the project } \\
\text { hand-over was delayed. }\end{array}$ \\
\hline
\end{tabular}


started in 2004. New project management arrangements were applied using recommendations from the aftermath of the Millennium Project. These included establishment of a Project Review Board to monitor progress, and appointment of a PRINCE2 practitioner as project manager. PRINCE2 is now a Government-mandate methodology for public projects.

Although the school was completed in 2007, hand-over was six months late due to design and construction issues. Elected members accused officers of failing to keep them informed of the delay.

Benefits in terms of parent satisfaction and enhancement to the reputation of the Council were noticed later.

\section{Project to implement a real-time} passenger information system for buses in the town. This project was commenced in 2002 and carried on until 2007. This was to utilise new technology. Unfortunately, no discussions were held between the council's IT service and the transport service which owned the project. As a result, software was procured that was incompatible with the existing Council infrastructure. The costs of this project were some $£ 6 \mathrm{M}$ over budget. The system could not be made to work and was turned off in 2006. A report by the Council's internal auditors showed that similar failings to those identified in Projects 1 and 2, despite two interventions to implement lessons previously learned.
Comments were made that this showed a 'blame culture' within the Council.

Reviews uncovered evidence of poor stakeholder engagement. This included difficulties with contractors and public disputes between elected Council members and officers.

Poor planning was highlighted.

Lack of any risk management or consideration of threats to the project was pointed out.

Recommendations were made for future practice.

Longer-term benefits had not been considered as part of the business case.

This was suggested to be a vanity project, initiated by an officer who wished to be seen as an expert.

Contract management was poor, so that contractors were paid for maintenance of a system that had not been fully implemented.

Unproven technology was selected without consulting the IT service.

Reviews revealed many issues: poor planning, no attempt at benefits management, poor stakeholder engagement, and no risk management.

There was evidence of poor oversight by senior managers who signed off the project.

All of these failings were despite recommendations on practice flowing from previous project reviews.

This project revealed, again, poor procurement processes and contract management.

Stakeholder engagement was poor.
4. Project to implement a 'Next Generation Finance System'.

The Council had previously conducted financial management supported by mainframe computing facilities hosted by the nearby County Council. This project 
was intended to replace this service with inhouse facilities.

At one stage, all 120 staff in the IT Service were working on this project. The new system never reached full implementation and the finance staff continued to use their own design spreadsheets. The project overspent its budget by $£ 2 \mathrm{M}$ and overran by two years.

As a result of this failure, potentially valuable management data was not available and managers were obliged to rely on finance staff to monitor their budgets. It also caused the Authority to fail its legal obligation to submit school accounts on time.
Poor planning was evidenced, including failure to include all necessary costs in the business case and budgeting.

This project highlights a point made by Marchand and Hykes (2006) that a key criterion for project success, going beyond cost, time and quality, should be 'use'.

\section{Table 2: Examples of projects undertaken at Exton Community Council}

The Council's record of project performance was poor when the study began in 2009, as judged by internal governance processes, reporting by the District Auditor and independent review by the Audit Commission. The early years of the new millennium saw several of the Council's high profile projects fail to deliver to time, budget, or requirements, and it faced criticism both from informed stakeholders and external observers, including the Press. For example, the local newspaper frequently ran critical articles detailing project failure and multiple correspondents in the letters page were quick to join in often with little knowledge of the facts. Two internal initiatives, in 2003 and again in 2006, failed to establish better practice. A review by external management consultants was then commissioned. However, by the end of 2007, no lasting improvement had resulted.

As the study commenced, it became clear that poor project performance was endemic and becoming a major issue within the Council. Evidence emerged showing a range of different causes, such as incomplete understanding of requirements for project delivery, poor planning, a lack of attention to benefits management, belief that a communications plan was sufficient to ensure good stakeholder engagement, poor risk management and high levels of distrust different stakeholder groups at senior level. It became clear that a different and systemic perspective on the situation was needed.

It should be noted that there were a number of projects during this time period that were experienced as successful and delivered good outcomes and real benefits. Examination of these suggested that success was due to the level of communication between team members and managers throughout the project, and in particular to excellent stakeholder engagement. These lessons were noted in the inquiry. 


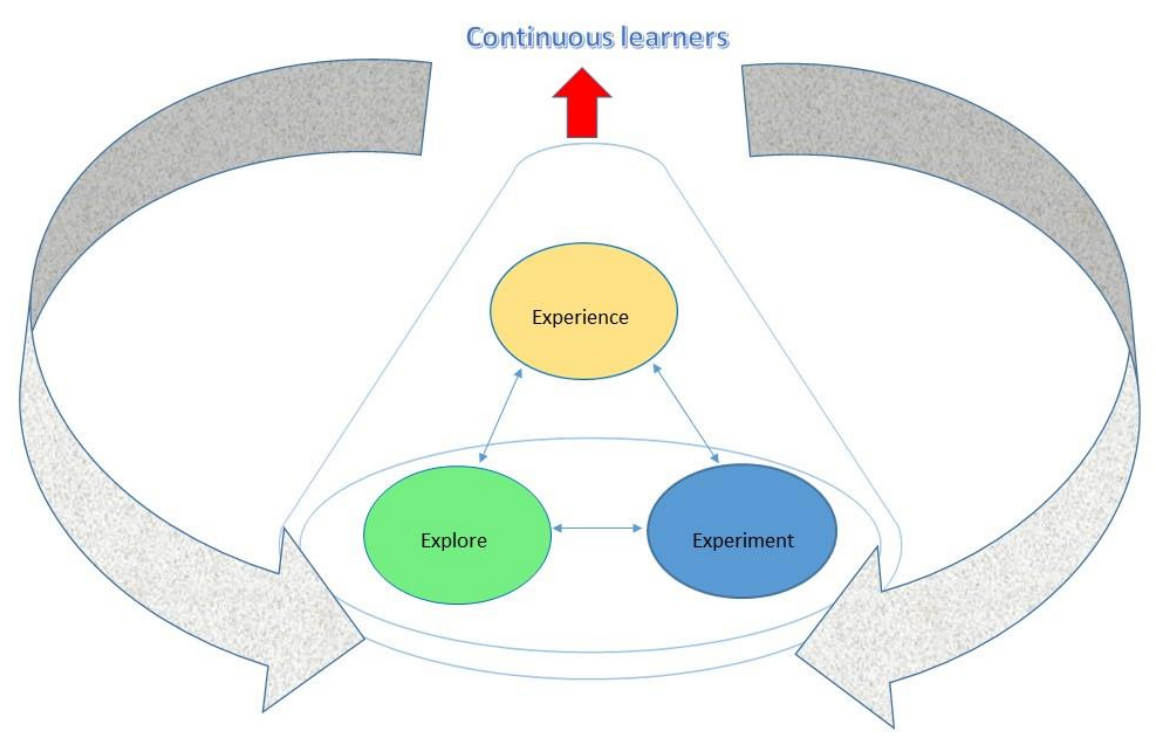

Figure 3: The Triple 'E' model - Explore, Experiment, Experience

A new intervention was undertaken from 2008. This was grounded in systemic thinking, drawing upon Vickers' concept of appreciation, Ackoff's approach to tackling problems (Ackoff, 1981, 1994) and Bateson's taxonomy of learning Bateson, 1972). The intervention involved a dual, iterative approach to appreciation. In one cycle, the inquirer explored the problem situation using many sources of information (see Table 3 ).

\section{Sources of information for appreciative learning}

\begin{tabular}{|l|l|}
\hline Formal and informal discussions with staff & $\begin{array}{l}\text { The situation was discussed across and } \\
\text { beyond the organisation. This included } \\
\text { senior managers, staff involved in project } \\
\text { delivery, finance managers and project staff } \\
\text { in other organisations }\end{array}$ \\
\hline Relevant literature and informed opinion & $\begin{array}{l}\text { Academic articles found in relevant } \\
\text { journals, as well as books written from both } \\
\text { academic and practitioner viewpoints. } \\
\text { Resources from the the Project Management } \\
\text { Institute and Association for Project } \\
\text { Management, PRINCE2 and Managing } \\
\text { Successful Programmes manuals. }\end{array}$ \\
\hline Practice found elsewhere & $\begin{array}{l}\text { Investigating the approaches taken by other } \\
\text { organisations through posts on the Local } \\
\text { Government Innovation \& Development } \\
\text { Network of Practice, their websites and }\end{array}$ \\
\hline
\end{tabular}




\begin{tabular}{|l|l|}
\hline & $\begin{array}{l}\text { discussions with staff from other public } \\
\text { sector bodies. }\end{array}$ \\
\hline $\begin{array}{l}\text { Formal opportunities for research and } \\
\text { discussion }\end{array}$ & $\begin{array}{l}\text { Attendance at conferences both academic } \\
\text { and practitioner based, combined with } \\
\text { discussions with academics and } \\
\text { practitioners at these events. }\end{array}$ \\
\hline Stakeholder engagement & $\begin{array}{l}\text { Workshops, designed around learning } \\
\text { activities and additionally used with project } \\
\text { delivery teams to create risk plans, benefit } \\
\text { plans, evaluation plans and stakeholder } \\
\text { engagement plans. }\end{array}$ \\
\hline Documentary evidence & $\begin{array}{l}\text { Project retrospectives, these were conducted } \\
\text { usually } 6 \text { to } 12 \text { months following the } \\
\text { delivery of the project output and explored } \\
\text { what went well, what did not go well, what } \\
\text { might be done differently and any other } \\
\text { learning. }\end{array}$ \\
\hline Communities of practice & $\begin{array}{l}\text { Both internal and external communities } \\
\text { within which experiences and ideas for good } \\
\text { practice were discussed. }\end{array}$ \\
\hline
\end{tabular}

Table 3: Sources of information for appreciative learning

Reflection upon the results launched a second iteration in which the inquirer drew in other stakeholders to discuss and reflect upon aspects of the situation, yielding further ideas for reflection, building a learning spiral to inform the progress of the inquiry itself. Drawing upon this first cycle, a second and parallel spiral progressed to draw upon the informed, contextual understandings of the various engaged stakeholders. This built a knowledge-based from which to promote beneficial change, through engagement and reflection. A schema for this approach to intervention is shown in Figure 3.

Cycles of inquiry/intervention led to design of a proposed model for bringing about improvement in project performance. This was promoted to stakeholders as 'ExploreExperiment-Experience' on an iterative basis. This is shown in Figure 4.

Exploring took the form of inquiry and discussion among engage actors. This phase emphasized gaining appreciation of projects and their context, including the expectations of stakeholders.

Experimenting emphasized floating of ideas, assessing responses of colleagues and other stakeholders and testing them in practice.

Experience related to situated practice of the engaged actors. Emphasis here was on sharing, collating, discussing and evaluating.

In applying this model within the Council's problem situation, an educational approach was highlighted, rather than the process compliance and enforcement approach to improvement 
endorsed by the UK government. Furthermore, the model served to move the focus of project management away from outputs delivered to specified cost and time constraints, towards achieving strategic objectives and value for the organization. A new staff development programme was introduced, designed around the 'Triple E' model - the Licenced Project Manager Development Programme. This was considered to be the most effective way to embed new behaviours in practitioners (Senior, 2002, p. 332) and thus of vital importance in sustaining improved project performance.

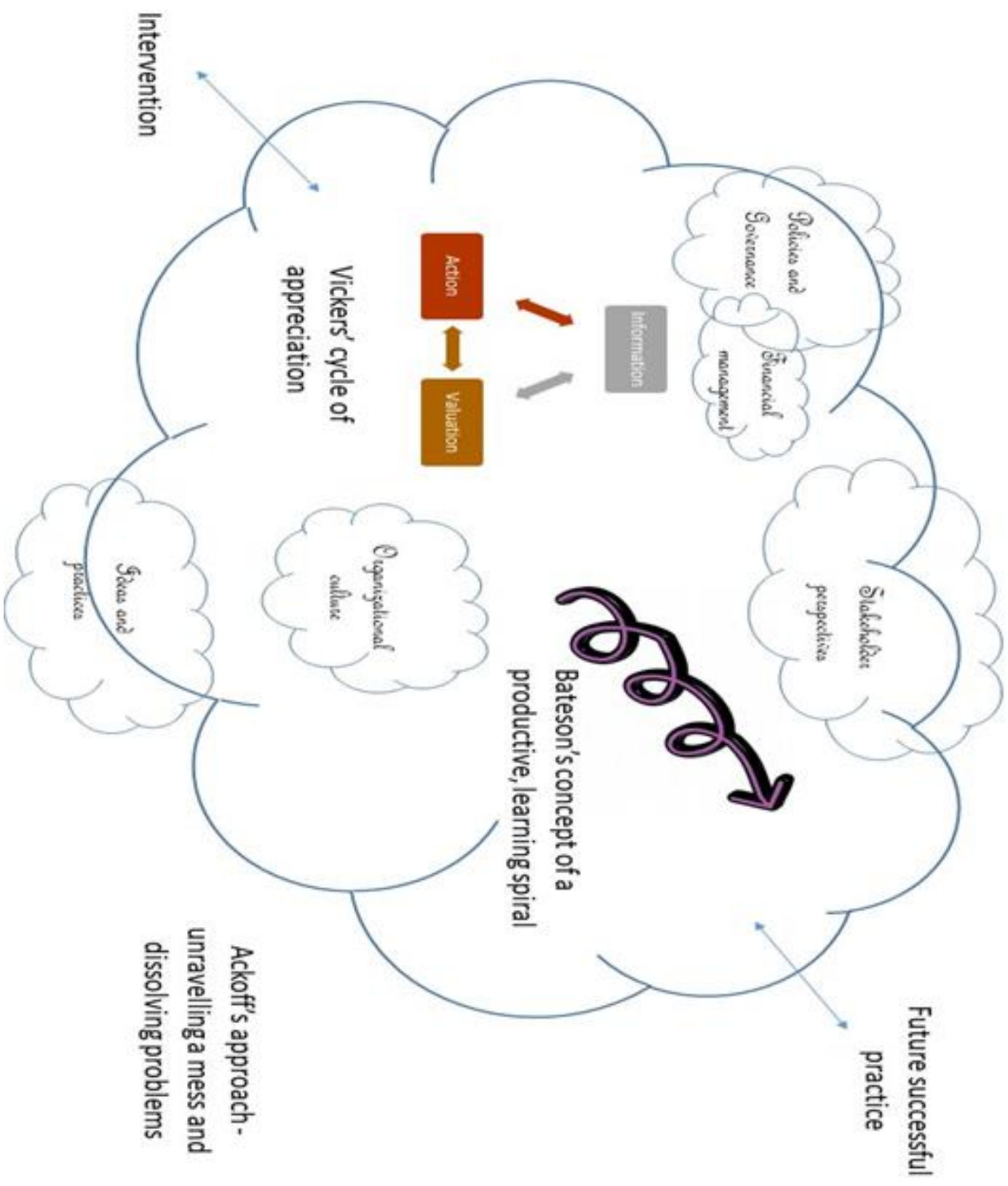


Figure 4: A schema for intervention at ECC using the Triple 'E' problem-structuring approach

In justifying an educational approach, due attention was paid to authors involved in the RPM network (Winter and Smith, 2006), who found that existing project management qualifications focused unduly on training practitioners to follow detailed procedures, bound by methodologies and tools, such as PRINCE2. They highlighted a need to develop practitioners who are adaptable and pragmatic (Crawford et.al., 2006, p. 724), (Winter et al. 2006, p. 646). Notwithstanding significant number of certified project managers, projects could still be seen to be failing with regularity, and unfortunately this position does not appear to be changing (Dalcher, 2003; Kapsali, 2013; The Standish Group, 2009, 2013; Thomas and Mengel, 2008). Crawford et. al., (2006, p. 724) considered practitioner development as both narrow and shallow. They suggested six imperatives for the future (see Table 4). These were taken into account in designing the LPMDP.

\section{Six Imperatives for Project Manager Development}

1. Flexibility to consider context of application
Project management practice is applied to a range of project types with characteristics that differ from those for which project management practices were first developed (e.g. government funded defencelaerospace and construction). Practitioners therefore need to demonstrate competence to adapt their practice to a variety of different contexts.

2. Extension of focus beyond execution/delivery

Project management vision must be expanded to a whole-of-life concept of projects - from initiation, through operation to cancellation/evaluation.

3. Change of horizon from product creation to value creation

Change of focus from product creation to value creation, from well-defined outputs to less tangible outcomes or benefits. Extension of the breadth of project management to include program and portfolio management in a broader conceptualisation of management of projects as a strategic corporate capability

4. Meeting challenge of Increasing actual and perceived complexity
For many reasons including changing societal values; increased stakeholder involvement and influence; more complex governance, ownership and delivery 


\begin{tabular}{|l|l|}
\hline & $\begin{array}{l}\text { structures; and advances in communication } \\
\text { technology that enable global and virtual } \\
\text { working, and accelerate time pressures. }\end{array}$ \\
\hline 5. Situated practice within business & $\begin{array}{l}\text { Integration with, rather than isolation of } \\
\text { projects from the business. }\end{array}$ \\
\hline 6. Coping with ageing of the workforce & $\begin{array}{l}\text { Addressing the need for succession } \\
\text { planning. }\end{array}$ \\
\hline
\end{tabular}

Table 4: Six Considerations in Design of Project Management Development Programmes (Adapted from Crawford et. al., 2006, pp. 724 - 725)

\section{Impact of the Model}

The Triple ' $E$ ' model was tested within the Council (in conjunction with the Licenced Project Management Practitioner Development Programme discussed below), and led to improvement in project performance that could be clearly evidenced from both business metrics and expressed stakeholder views. It continued to be refined over time through further engaged inquiry in communities of reflective practice. Use of this model, in combination with the new approach to staff development, could be expected to lead to a sustainable transformation in practice for the future.

For example, the local newspaper frequently ran critical articles detailing project failure and multiple correspondents in the letters page were quick to join in often with little knowledge of the facts.

The model was designed after gaining an appreciation of the state of project performance within the Council and a review of the practice in other organisations investigating their approach to the management of projects. This involved an 'engaged scholarship' (Van de Ven, 2007) approach to constructing the dual cycle used and described in this chapter.

The model had three underpinning concepts. Firstly, it was based on an educational approach rather than the process compliance and enforcement approach previously applied when attempting to improve project performance. Secondly the model is intended to move the focus from an output delivered to specified cost and time constraints onto achieving strategic objectives and value for the organisation. Thirdly, Vickers 'appreciative system of learning' (Vickers, 1983) synthesised with Ackoff's problem-solving paradigm (Ackoff, 1981, 1994) and the work of Bateson (Bateson, 1972) were the key underpinning influences throughout the dual cycle of activities.

This Triple 'E' approach was applied iteratively, through problem-solving activity and creation of a development programme introduced for project staff. This concept derived from Vickers' 'appreciative system of learning' of information, valuation, action in a continuous cycle (Vickers, 1983), building into a productive learning spiral (Bateson, 1972). Exploring took the form of inquiry and discussing concepts with stakeholders, drawing on experience in the workplace. This promoted an appreciation of the nature of projects and the expectations of stakeholders. Experimentation was about floating ideas, assessing responses and testing them in practice. Experiences of the stakeholders were surfaced through discussion, shared 
and collated. Iterations of this process moved the learning spiral onwards. Figure 5 shows the practical improvement model designed through the Triple ' $E$ ' problem-structuring approach.

The model shows how attention was focused on project performance through peer review by a Project Management Group. This group formed a Community of Practice, which engaged in active learning on a continuous basis, sharing understandings of practice and making use of coaching and mentoring where appropriate.

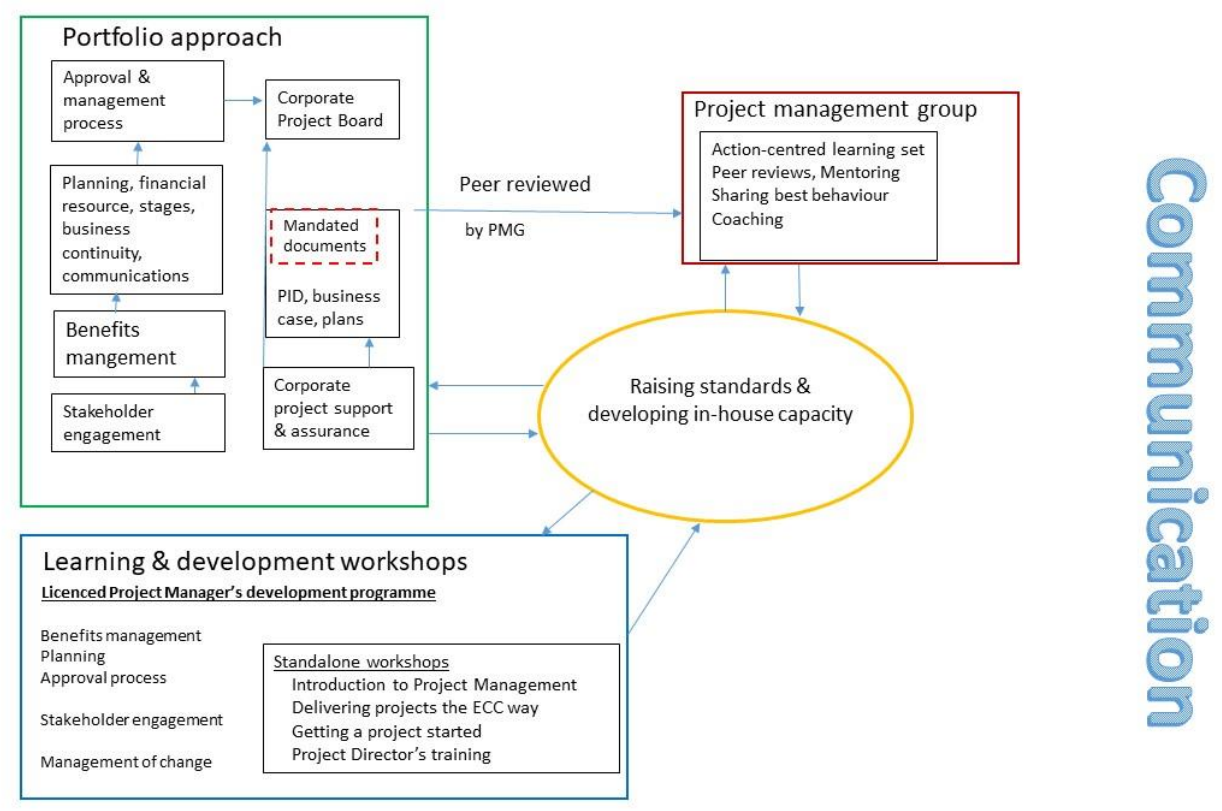

Figure 5: Practical Improvement Model, based on Triple 'E'

A portfolio approach to management was introduced at an early stage and nurtured through this process of peer review and using a set of mandated documentation. Within the portfolio approach, an expanded project life cycle was adopted, explicitly including both stakeholder engagement and a focus on 'real world' benefits desired from projects by their sponsors and other stakeholders. Communication was emphasised as a key feature of practice at all stages and levels of the model, as was an on-going endeavour to raise standards and develop inhouse capacity using feedback and learning.

This model proved successful within ECC, as the number of projects experienced as failures was drastically reduced and the approach to appreciation and learning become embedded as normal practice. Some seven years after its inception, the approach is still in use. While the key features of communication, attention management and genuine stakeholder engagement are highlighted, this chapter is not intended to suggest that the Practical Improvement Model might be copied as 'best practice' by project management teams in other authorities or contexts. Rather, its success is to be seen as indicative of what could be achieved by teams engaging in appreciative learning for themselves, using the Triple ' $E$ ' approach, to build models of practice that work for them. 


\section{References}

Ackoff, R. L. (1974). Redesigning the future: A systems approach to societal problems. New York: John Wiley \& Sons Inc.

Ackoff, R.L. (1981). Creating the Corporate Future: Plan or be Planned For. New York: John Wiley \& Sons.

Ackoff, R. L. (1994). Systems thinking and thinking systems. System Dynamics Review, 10(2-3), 175-188.

Association for Project Management. (2012). APM Body of Knowledge, 6th edition, Princes Risborough: APM.

Atkinson, R. (1999). Project management: cost, time and quality, two best guesses and a phenomenon, it's time to accept other success criteria. International Journal of Project Management, 17(6), 337-342.

Atkinson, R., Crawford, L., \& Ward, S. (2006). Fundamental uncertainties in projects and the scope of project management. International Journal of Project Management, 24(8), 687698.

Bateson, G. (1972). Steps to an ecology of the mind. Chicago: University of Chicago Press

Bednar, P.M. (2000). A Contextual Integration of Individual and Organizational Learning Perspectives as Part of IS Analysis. Informing Science: Journal of an Emerging Transdiscipline, 3(3), 145 - 156.

Bednar, P. (2007). Individual Emergence in Contextual Analysis. Systemica, 14(1-6), n.p.

British Standards Institute. (2010). Project management BS 6079-1:2010. In Principles and guidelines for the management of projects (pp. 72). London: British Standards Institute.

Burke, R. (2011). Advanced Project Management: Fusion Method. Hong Kong: Burke Publishing.

Checkland, P. (1999). Systems Thinking, Systems Practice: a 30-year Retrospective. Chichester: J. Wiley \& Sons.

Checkland, P. and Holwell, S. (1998). Information, systems and information systems: making sense of the field. Chichester: John Wiley \& Sons.

Checkland, P. and Poulter, J. (2006). Learning for Action. Chichester: J. Wiley \& Sons.

Checkland, P. and Poulter, J. (2010). Soft Systems Methodology. Chapter 5 in M. Reynolds and S. Holwell (editors), Systems Approaches to Managing Change: A Practical Guide. London: Springer.

Cooke-Davies, T. (2002). The "real" success factors on projects. International Journal of Project Management, 20(3), 185-190.

Crawford, L., and Costello, K. (2000). Towards a transferable methodology for managing strategic change by projects. Proceedings of the IRNOP IV Conference-Paradoxes of 
Project Collaboration in the Global Economy: Interdependence, Complexity and Ambiguity. Fourth International Conference of the International Research Network of Organizing by Projects, 136-146 IRNOP IV: University of Technology, Sydney, Australia.

Crawford, L., Morris, P., Thomas, J., \& Winter, M. (2006). Practitioner development: From trained technicians to reflective practitioners. International Journal of Project Management, 24(8), 722-733.

Dalcher, D. (2003). Understanding Stories of Information Systems Failures. In Goldkuhl, G. (Ed), Proceedings of the Action in Language, Organisations and Information Systems (ALOIS), Linköping, Sweden 12-13 March 2003, pp 221-236.

Dalcher, D. (2016). Business cases, benefits and potential value: The impact of planning fallacy, optimism bias and strategic misrepresentation on the road to success. PM World Journal, $V(\mathrm{VI}), 1-7$.

Davenport, T.H. and Prusak, L. (2000). Working Knowledge: How Organizations Manage What They Know. Cambridge, MA: Harvard Business Review Press.

Davenport, T.H., and Völpel, S.C. (2001). The rise of knowledge towards attention management, Journal of Knowledge Management, 5(3), 212-222.

Kapsali, M. (2013). Equifinality in project management exploring causal complexity in projects. Systems Research and Behavioral Science, 30(1), 2-14.

Kerzner, H. and Saladis, F.P. (2009). Value-Driven Project Management. New York: J. Wiley \& Sons.

Lenfle, S. and Loch, C.H. (2010). Lost Roots: How Project Management Came to Emphasize Control Over Flexibility and Novelty, California Management Review, 53(1), 32-55

Marchand, D. and Hykes, A. (2006). IMD Perspectives for Managers No.138, 'Designed to Fail: Why IT-enabled Business Projects Underachieve, 15th European Conference, St Gallen, Switzerland, Accessed 11 November 2017 at http://www.ecis2007.ch/conference_programme.php.

Morecroft, J.D.W. (1985). The feedback view of business policy and strategy. System Dynamics Review, 1(1), 4-19.

Morris, P. W. G. (2013). Reconstructing Project Management. Somerset, N.J.: Wiley Morris,

Mumford, E. (2006). The story of socio-technical design: reflections in its successes, failures and potential, Information Systems Journal, 16,4 317-342.

Office of Government Commerce. (2009). Managing Successful Projects with PRINCE2. UK: The Stationery Office.

Pidd, M. (2009). Tools for Thinking: Modelling in Management Science, 3rd Edition. New York: J Wiley \& Sons.

Project Management Institute. (2008). A guide to the project management body of knowledge (4th ed.): PMI.

Senior, B. (2002). Organisational Change (2nd ed.). London: Prentice Hall. 
Simon, H. A. (1956). Rational choice and the structure of the environment. Psychological Review, 63(2), 129 - 138.

Stacey, R.D. (1992). Managing the Unknowable: Strategic Boundaries Between Order and Chaos in Organizations. San Francisco: Jossey-Bass.

Stacey, R. D. (1996). Complexity and Creativity in Organisations. San Francisco: BerretKoehler.

The Standish Group. (2009). CHAOS Summary 2009. Accessed 12 November 2017 from http://www.standishgroup.com/newsroom/chaos_2009.php

The Standish Group. (2013). The CHAOS manifesto 2013. Accessed 12 November 2017 from http://thestandishgroup.com

Thomas, J., and Mengel, T. (2008). Preparing project managers to deal with complexity Advanced project management education. International Journal of Project Management, 26(3), 304-315.

Van de Ven, A.H. (2007). Engaged Scholarship: a Guide for Organizational and Social Research. New York: Oxford University Press.

Vickers, G. (1965). The art of judgment: A study of policy making. Basic Books.

Vickers, G. (1968). Value systems and social process. Harmondsworth: Penguin Books.

Vickers, G. (1983). Human systems are different. London: Harper and Row.

Von Bertalanffy, L. (1950). An Outline of General System Theory, British Journal for the Philosophy of Science, 1, p. 114-129.

Whitty, S. J., and Maylor, H. (2009). And then came Complex Project Management (revised). International Journal of Project Management, 27(3), 304-310.

Winter, M., and Smith, C. (2006). Rethinking Project Management. Report of EPSRC project. Accessed 20 November 2017 at http://www.ronrosenhead.co.uk/wpcontent/rethinking-project-management1.pdf.

Winter, M., Smith, C., Morris, P. W. G., \& Cicmil, S. (2006). Directions for future research in project management: The main findings of a UK government-funded research network. International Journal of Project Management, 24(8), 638-649. 